\title{
Pengaruh Manajemen Modal Kerja Terhadap Profitabilitas Perusahaan Non Keuangan Yang Terdaftar di Bursa Efek Indonesia
}

\author{
Hanifa Bennu Nur ${ }^{1}$, Nur Khusniyah Indrawati ${ }^{2}$, Kusuma Ratnawati ${ }^{3}$ \\ ${ }^{1}$ Program Studi Magister Manajemen, Fakultas Ekonomi dan Bisnis, Universitas Brawijaya \\ 2Program Studi Magister Manajemen, Fakultas Ekonomi dan Bisnis, Universitas Brawijaya \\ ${ }^{3}$ Program Studi Magister Manajemen, Fakultas Ekonomi dan Bisnis, Universitas Brawijaya
}

\begin{abstract}
Abstrak
Penelitian ini mempelajari pengaruh manajemen modal kerja terhadap profitabilitas perusahaan non keuangan yang terdaftar di Bursa Efek Indonesia. Variabel yang digunakan untuk mengukur manajemen modal kerja adalah cash conversion cycle, gross working capital turnover ratio, current assets to total assets ratio, current liabilities to total assets ratio, dan current ratio, sedangkan profitabilitas diukur dengan return on assets dan return on equity. Perusahaan yang diteliti sebanyak 139 perusahaan non keuangan untuk seluruh sektor, kemudian dianalisis lagi untuk masing-masing sektor yaitu sektor utama (industri penghasil bahan baku), sektor kedua (industri manufaktur), dan sektor ketiga (industri jasa), dengan periode penelitian tahun 2011-2013. Dengan menggunakan analisis regresi berganda, hasil yang diperoleh adalah manajemen modal kerja tidak mempunyai pengaruh terhadap profitabilitas perusahaan non keuangan untuk seluruh sektor. Pengaruhnya terjadi hanya pada sektor utama (industri penghasil bahan baku). Hal ini menunjukkan bahwa manajemen modal kerja bukan merupakan penentu bagi peningkatan profitabilitas perusahaan. Manajemen modal kerja belum dikelola secara efektif dan efisien untuk menciptakan penjualan sehingga menghasilkan keuntungan bagi perusahaan.
\end{abstract}

Kata kunci : Perusahaan non keuangan, manajemen modal kerja, profitabilitas

\begin{abstract}
This research studied the effect of working capital management on the profitability of non-financial companies listed on the Indonesia Stock Exchange. Variables used to measure working capital management is the cash conversion cycle, gross working capital turnover ratio, current assets to total assets ratio, current liabilities to total assets ratio and current ratio, while profitability measured by return on assets and return on equity. The company studied as much as 139 non-financial companies for the entire sector, then analyzed again for each sector in the main sector (industries producing raw materials), the second sector (manufacturing industry), and the third sector (service industry), with a study period of 2011 2013. By using multiple regression analysis, the study shows that working capital management has no effect on the profitability of non-financial companies for the entire sector. The effects may occur only on the main sector (industries producing raw materials). This shows that the management of working capital is not a determinant for increasing profitability. Working capital management has not been managed effectively and efficiently to create sales resulting in a profit for the company.
\end{abstract}

Keywords : non-financial company, working capital management, profitability

\section{PENDAHULUAN}

Manajemen modal kerja dianggap sebagai elemen yang sangat penting untuk menganalisis kinerja organisasi saat melakukan operasi seharihari, di mana keseimbangan dapat dipertahankan antara likuiditas dan profitabilitas [1]. Manajemen modal kerja merupakan komponen yang sangat penting dari keuangan perusahaan karena langsung memengaruhi likuiditas dan profitabilitas perusahaan [2]

Alamat Korespondensi Penulis:

Hanifa Bennu Nur

Email : hanibennunur@gmail.com, HP. 082234464944

Alamat : Jln. Ir. Putuhena, Poka, Ambon. 97128

Manajemen modal kerja yang efektif dan efisien sangat dibutuhkan pada industri nonkeuangan yang fungsi utama unit institusionalnya adalah memproduksi barang-barang komersial atau jasa non-keuangan. Namun karena sifatnya yang jangka pendek, maka pengelolaan manajemen modal kerja ini sering kali luput dari perhatian. Padahal, manajemen modal kerja yang buruk akan mengakibatkan perusahaan tidak dapat memenuhi kewajiban jangka pendeknya yang akan segera jatuh tempo, sehingga akan berdampak pada financial distress.

Manajemen modal kerja menjadi sangat penting dalam perusahaan karena beberapa alasan: Pertama, proporsi aktiva lancar perusahaan manufaktur biasanya lebih dari separuh total aktivanya. Kedua, bagi perusahaan distribusi, 
jumlahnya bahkan lebih besar lagi. Ketiga, bagi perusahaan kecil, kewajiban jangka pendek adalah sumber utama dari pendanaan eksternal. Adanya alasan-alasan inilah sebabnya para manajer keuangan dan staf keuangan mendedikasikan sebagian besar waktunya untuk berbagai masalah modal kerja [3]. Pemanfaatan modal kerja yang optimal dengan sendirinya akan meningkatkan profitabilitas perusahaan.

Beberapa penelitian sebelumnya menemukan pengaruh negatif dan signifikan antara cash conversion cycle dengan return on assets [1,4-8]. Hal ini sejalan dengan teori bahwa dengan mengurangi cash conversion cycle maka profitabilitas perusahaan akan meningkat dan sebaliknya. Namun lain halnya dengan Afeef yang menemukan pengaruh positif dan tidak signifikan antara cash conversion cycle dengan return on assets [9], hal senada juga diungkapkan oleh Uchenna, et al., yang menemukan pengaruh positif dan signifikan antara variabel cash conversion cycle terhadap return on assets [10]. Selain cash conversion cycle, variabel modal kerja lain seperti gross working capital turnover ratio, current assets to total assets ratio, current liabilities to total assets ratio dan current ratio juga merupakan komponen dari modal kerja yang turut memengaruhi efisiensi dan efektifitas manajemen modal kerja karena terkait dengan aset lancar dan kewajiban lancar $[1,5]$.

Gross working capital turnover ratio digunakan untuk melihat tingkat perputaran modal kerja. Beberapa penelitian sebelumnya menemukan pengaruh positif signifikan gross working capital turnover ratio terhadap profitabilitas [1,11,12].

Current assets to total assets ratio digunakan untuk mengukur struktur aset. Beberapa penelitian sebelumnya menemukan pengaruh positif signifikan current assets to total assets ratio terhadap profitabilitas $[1,5,6,12]$.

Current liabilities to total assets ratio digunakan untul melihat pendanaan modal kerja. Beberapa penelitian sebelumnya menemukan pengaruh negatif signifikan current liabilities to total assets ratio terhadap profitabilitas [5,11].

Current ratio merupakan salah satu rasio likuiditas, yang bertujuan untuk mengukur kemampuan suatu perusahaan dalam memenuhi kewajiban jangka pendeknya. Beberapa penelitian sebelumnya menyatakan bahwa current ratio berpengaruh positif dan signifikan terhadap profitabilitas [1,10-12].

Mengingat pentingnya peranan modal kerja pada sebuah perusahaan maka dirasa perlu untuk dilakukan penelitian tentang pengaruh manajemen modal kerja terhadap profitabilitas perusahaan non keuangan yang terdaftar di Bursa Efek Indonesia (BEI) untuk seluruh sektor dan masing-masing sektor, yang mencakup: 1) sektor utama (industri penghasil bahan baku), 2) sektor kedua (industri manufaktur), dan 3) sektor ketiga (industri jasa di luar sektor keuangan).

Tujuan penelitian ini adalah menguji dan menganalisis pengaruh cash conversion cycle, gross working capital turnover ratio, current assets to total assets ratio, current liabilities to total assets ratio, current ratio terhadap return on assets dan return on equity perusahaan non keuangan yang terdaftar di Bursa Efek Indonesia untuk seluruh sektor dan masing-masing sektor.

\section{METODE PENELITIAN}

\section{Jenis Penelitian}

Penelitian ini tergolong dalam penelitian kuantitatif. Jenis penelitian ini merupakan penelitian pengujian hipotesis (hypothesis testing). Desain penelitian ini termasuk dalam desain kausal yaitu jenis desain yang digunakan untuk menganalisis hubungan-hubungan antar variabel yang saling memengaruhi, sedangkan karakteristik penelitian ini adalah Explanatory Research yang menyoroti hubungan antara variabel-variabel penelitian dan menguji hipotesis yang dirumuskan. Populasi

Populasi dalam penelitian ini adalah emiten yang usahanya diklasifikasikan dalam industri non keuangan yang ditetapkan oleh Bursa Efek Indonesia (BEI) yaitu sebanyak 419 perusahaan yang terdaftar, kemudian ditentukan kriteria:

1. Perusahaan yang terdaftar sesuai tanggal IPO setelah tahun 2010.

2. Perusahaan yang dalam laporan keuangannya memiliki komponen persediaan, piutang usaha dan utang usaha.

3. Perusahaan yang tidak mengalami kerugian pada periode penelitian.

Berdasarkan kriteria populasi tersebut, diperoleh sejumlah 230 perusahaan memenuhi syarat.

Sampel

Penentuan ukuran sampel dalam penelitian ini mengacu pada tabel penentuan jumlah sampel dari populasi tertentu dengan taraf kesalahan $1 \%$, $5 \%$, dan $10 \%$ yang dikembangkan oleh Isaac dan Michael [13]. Berdasarkan tabel Isaac dan Michael, dengan jumlah populasi perusahaan non keuangan pada BEI sebanyak 230 perusahaan dan taraf kesalahan 5\% diperoleh besar sampel sebanyak 139 perusahaan.

Penentuan besar sampel dari masingmasing sub sektor menggunakan teknik proportionate stratified random sampling. Teknik ini digunakan bila populasi mempunyai 
anggota/unsur yang tidak homogen dan berstrata secara proporsional [13].

\section{Teknik Pengumpulan Data}

Penelitian ini menggunakan data sekunder (secondary data). Data sekunder yang digunakan dalam penelitian berupa data profil perusahaan dan data laporan keuangan perusahaan non keuangan yang terdaftar di Bursa Efek Indonesia (BEI) yang bersumber dari situs resmi BEI (www.idx.co.id). Metode pengumpulan data menggunakan teknik dokumentasi.

\section{Teknik Analisis Data}

Teknik analisis data dalam penelitian ini menggunakan analisis regresi berganda bantuan program SPSS versi 20.0.

Persamaan regresi yang disusun untuk penelitian ini adalah:

$\mathrm{ROA}_{i \mathrm{t}}=\beta_{0}+\beta_{1} \mathrm{CCC}_{\mathrm{it}}+\beta_{2} \mathrm{GWCTR}_{\mathrm{it}}+\beta_{3} \mathrm{CATAR}_{\mathrm{it}}+\beta_{4} \mathrm{CLTAR}_{\mathrm{it}}+\beta_{5} \mathrm{CR}_{\mathrm{it}}+e$ $\mathrm{ROE}_{i \mathrm{t}}=\beta_{0}+\beta_{1} \mathrm{CCC}_{\text {it }}+\beta_{2} \mathrm{GWCTR}_{\mathrm{it}}+\beta_{3} \mathrm{CATAR}_{\mathrm{it}}+\beta_{4} \mathrm{CLTAR}_{\mathrm{it}}+\beta_{5} \mathrm{CR}_{\mathrm{it}}+e$ Keterangan :

$\mathrm{ROA}_{\mathrm{it}} \quad=$ Return on Assets perusahaan i dan waktu $\mathrm{t}$

$\mathrm{ROE}_{\mathrm{it}} \quad=$ Return on Equity perusahaan i dan waktu $\mathrm{t}$

$\mathrm{CCC}_{\text {it }} \quad=$ Cash Conversion Cycle perusahaan i dan waktu $\mathrm{t}$

GWCTR $_{\text {it }} \quad$ Gross Working Capital Turnover Ratio perusahaan i dan waktu t

CATAR $_{\text {it }} \quad=$ Current Assets to Total Assets Ratio (CATAR)

CLTAR $_{\text {it }}=$ Current Liabilities to Total Asset Ratio (CLTAR)

CATAR $_{\text {it }}=$ Current Ratio (CR)

$\beta_{0} \quad=$ Konstanta

$\beta_{1} \quad=$ Koefisien Cash Conversion Cycle (CCC)

$\beta_{2} \quad=$ Koefisien Gross Working Capital Turnover Ratio (GWCTR)

$\beta_{3} \quad=$ Koefisien Current Assets to Total Assets Ratio (CATAR)

$\beta_{4} \quad=$ Koefisien Current Liabilities to Total Asset Ratio (CLTAR)

$\beta_{5} \quad=$ Koefisien Current Ratio (CR)

e error

Untuk menghitung masing-masing variabel digunakan rumus sebagai berikut:

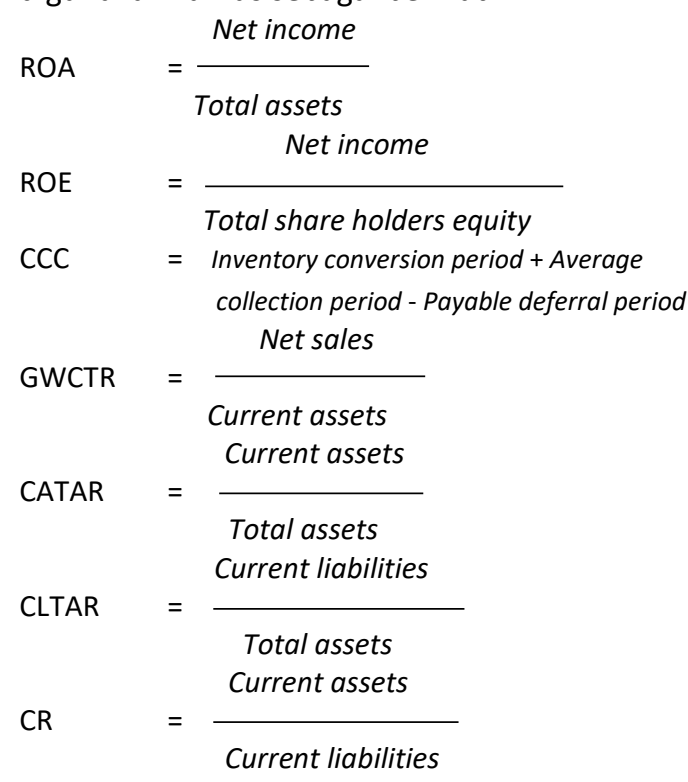

\section{HASIL DAN PEMBAHASAN}

\section{Gambaran Obyek Penelitian}

Obyek penelitian ini adalah perusahaan non keuangan yang merupakan perusahaan yang bergerak di sektor riil, menghasilkan barang atau jasa, dan terdaftar di Bursa Efek Indonesia. Penelitian dilakukan pada seluruh sektor dengan jumlah sampel sebanyak 139 perusahaan, kemudian terbagi lagi ke dalam masing-masing sektor, yaitu: 1) sektor utama (industri penghasil bahan baku) sebanyak 17 perusahaan, 2) sektor kedua (industri manufaktur) sebanyak 56 perusahaan, dan 3) sektor ketiga (industri jasa) sebanyak 66 perusahaan.

\section{Deskripsi Variabel Penelitian}

Berdasarkan hasil pengolahan data secara statistik dapat dilihat pada Tabel terlampir, maka deskripsi variabel penelitian perusahaan sampel selama tahun pengamatan diperoleh rata-rata cash conversion cycle untuk seluruh sektor pada tahun pengamatan cukup lama konversinya. Siklus konversi kas terpendek terjadi pada tahun 2012 yaitu 196 hari, angka ini merupakan sik(u)s terbaik selama tahun pengamatan untuk selurưh sektor, namun masih cukup lama periodenya. Sedangkan, untuk masing-masing sektor, rata-rata siklus konversi kas tercepat terjadi pada sektor utama (industri penghasil bahan baku) dan sektor kedua (industri manufaktur) yang berkisar kurang lebih 100 hari, artinya proses dari keluarnya kas sampai dengan masuknya kas dari hasil penjualannya membutuhkan waktu \pm 100 hari. Sedangkan sektor industri jasa memiliki rata-rata siklus konversi kas terlama, bahkan sampai mencapai rata-rata 311 hari pada tahun 2011. Hal ini disebabkan karena periode konversi persediaan dan periode penerimaan rata-rata perusahaan pada sektor ini rata-rata terlalu lama, sehingga nilai siklusnya menjadi sangat besar.

Variabel gross working capital turnover ratio memiliki nilai rata-rata untuk seluruh sektor selama tahun pengamatan cukup rendah. Hal ini menunjukkan rata-rata kemampuan modal kerja berputar untuk menghasilkan penjualan cukup rendah. Perputaran modal kerja terbaik terjadi pada tahun 2011 dan 2012 yaitu sebanyak 2 kali per tahun. Sedangkan untuk masing-masigg sektor, yaitu sektor utama dan sektor kedua, rata-rata gross working capital turnover ratio cukup baik yaitu lebih dari 2 kali per tahun, dibałddingkan sektor ketiga yang rata-rata tidak mencapai 2 kali per tahun. Hal ini disebabkan karena perusahaan pada sektor utama dan sektor kedua lebli banyak memanfaatkan modal kerja dibandingkan perusahaan pada sektor ketiga yang lebib) banyak memanfaatkan aktiva tetapnya.

Variabel current assets to total assets ratio memiliki nilai rata-rata cukup stabil untuk semua sektor pada tahun pengamatan. Hal ini menunjukkan rata-rata aktiva lancar yang tersedia mampu menunjang kebutuhan operasional perusahaan untuk meningkatkan penjualan. Angka 
rata-rata terendah terjadi pada sektor utama yang tidak mencapai $50 \%$ artinya untuk sektor utama proporsi aset lancar dari total aset yang dimiliki perusahaan tidak mencapai 50\% karena aset lancar senantiasa berputar sehingga modal kerja yang tertanam tidak menganggur, sedangkan angka terbesar terjadi pada tahun 2012 untuk semua sektor kecuali sektor utama yang mencapai lebih dari $60 \%$. Hal ini menunjukkan bahwa lebih dari separuh aset yang dimiliki oleh perusahaan adalah aset lancar.

Variabel current liabilities to total assets ratio memiliki nilai rata-rata relatif stabil pada semua sektor. Nilai rata-rata terendah terjadi pada sektor utama pada semua tahun pengamatan yaitu berkisar rata-rata $20 \%$, artinya nilai utang lancar terhadap kekayaan yang dimiliki perusahaan yang dimanfaatkan pada sektor ini tidak lebih dari $20 \%$. Sedangkan sektor kedua dan sektor ketiga memiliki rata-rata lebih dari 30\%, yang berarti bahwa perusahaan pada kedua sektor ini memiliki nilai utang lancar lebih dari 30\% persen dari total aset perusahaan yang dimanfaatkan dalam operasional perusahaan.

Variabel current ratio memiliki nilai ratarata untuk semua sektor pada seluruh tahun pengamatan lebih dari $200 \%$, kecuali untuk sektor industri jasa pada tahun 2011 dan 2013 besarnya sekitar $180 \%$. Melihat besarnya angka ini menunjukkan bahwa rata-rata perusahaan sampel berada pada posisi likuid. Nilai aktiva lancarnya mampu menutupi kewajiban lancarnya. Sebagai pedoman umum, nilai current ratio $200 \%$ sudah dianggap baik, khususnya bagi perusahaan industri (Moeljadi, 2006).

Variabel return on assets memiliki nilai ratarata selama periode pengamatan cukup rendah, yaitu tidak mencapai $10 \%$, artinya rata-rata pertumbuhan pengembalian atas aset per tahun cukup rendah. Hal ini mengindikasikan tingkat keuntungan yang diperoleh perusahaan selama tahun pengamatan relatif kecil. Angka terbesar terdapat pada sektor utama (industri penghasil bahan baku) tahun 2011 yaitu sebesar 15,14\%, sedangkan rata-rata terendah terdapat pada sektor ketiga (industri jasa) tahun 2011 yaitu sebesar 7,65\%. Untuk seluruh sektor angka terendah terjadi pada tahun 2013 yaitu sebesar $8,54 \%$.

Variabel return on equity memiliki nilai ratarata lebih dari $15 \%$, kecuali pada sektor utama (industri penghasil bahan baku) tahun 2011 mencapai $24,57 \%$. Angka rata-rata ini tergolong rendah, hal itu berarti perusahaan belum mampu memanfaatkan modal sendirinya untuk operasional perusahaan, atau modal sendirinya lebih tinggi dari nilai keuntungan yang diperoleh perusahaan.

\section{Uji Asumsi Klasik \\ Uji Normalitas}

Dari hasil pengujian normalitas dengan menggunakan One Sample Kolmogorov Smirnov Test menunjukkan bahwa seluruh variabel penelitian untuk seluruh sektor dan masing-masing sektor berada di atas 0,05, hasil tersebut mengindikasikan data residual berdistribusi normal karena signifikansi $>0,05$.

\section{Uji Multikolinearitas}

Hasil pengujian multikolinearitas dengan melihat nilai VIF menunjukkan semua angka VIF variabel model regresi lebih kecil dari 10 (VIF < 10). $\mathrm{Hal}$ ini menunjukkan model regresi linier berganda tidak mempunyai persoalan multikolinearitas. Hasil perhitungan nilai tolerance juga menunjukkan tidak ada variabel independen yang nilainya kurang dari 0,1 (tolerance $<0,1$ ), yang berarti tidak ada korelasi antar variabel independen yang nilainya lebih dari 95\%, hal ini berarti tidak terjadi multikolinearitas.

\section{Uji Heteroskedastisitas}

Hasil analisis statistik dengan menggunakan scatterplot menghasilkan sebaran titik data tidak menunjukkan pola tertentu. Dengan demikian dapat disimpulkan bahwa tidak terjadi gejala heteroskedastisitas. Hal ini juga dibuktikan dengan hasil analisis dengan menggunakan uji Park yang menunjukkan koefisien variabel independen tidak ada yang signifikan maka dapat disimpulkan bahwa model regresi tidak terdapat heteroskedastisitas.

\section{Pengujian Hipotesis}

Pengaruh variabel manajemen modal kerja terhadap profitabilitas dianalisis dengan menggunakan analisis regresi berganda yang dilakukan untuk seluruh sektor dan masing-masing sektor.

Hasil analisis regresi berganda dan pengujian hipotesis untuk seluruh sektor disajikan pada Tabel 1 dan Tabel 2 berikut.

Tabel 1.

Hasil analisis regresi untuk seluruh sektor model 1

\begin{tabular}{|c|c|c|c|c|c|}
\hline \multirow[t]{3}{*}{ Model } & \multicolumn{5}{|c|}{1} \\
\hline & \multicolumn{2}{|c|}{ Unstd. Coef. } & \multirow[t]{2}{*}{$t$} & \multirow[t]{2}{*}{ Sig. } & \multirow{2}{*}{$\begin{array}{l}\text { Pengujian } \\
\text { Hipotesis }\end{array}$} \\
\hline & B & Std. Err. & & & \\
\hline (Const.) &,- 546 & 1,678 &,- 325 & ,745 & \\
\hline CCC & 002 & ,004 &,- 251 & 802 & H1 ditolak \\
\hline GWCTR & 2,303 & ,368 & 6,253 & ,000 & $\mathrm{H} 2$ diterima \\
\hline CATAR & , 036 & ,024 & 1,511 & 132 & H3 ditolak \\
\hline CLTAR &,- 004 & 038 &,- 103 & 918 & H4 ditolak \\
\hline CR & ,015 & ,005 & 3,179 & ,002 & H5 diterima \\
\hline$\alpha$ & \multicolumn{5}{|l|}{$5 \%$} \\
\hline Adj. $R^{2}$ & \multicolumn{5}{|l|}{0,126} \\
\hline F-hit & \multicolumn{5}{|l|}{12,919} \\
\hline Sig. F-hit & \multicolumn{5}{|l|}{0,000} \\
\hline
\end{tabular}


Hasil analisis pada Tabel 1. menunjukkan bahwa untuk seluruh sektor, variabel cash conversion cycle, current assets to total assets ratio, dan current liabilities to total assets ratio tidak berpengaruh terhadap return on assets, yang dibuktikan dengan hasil pengujian $\mathrm{H} 1, \mathrm{H} 3$ dan $\mathrm{H} 4$ ditolak. Sedangkan variabel gross working capital turnover ratio dan current ratio berpengaruh positif signifikan terhadap return on assets yang dibuktikan dengan $\mathrm{H} 2$ dan $\mathrm{H} 5$ diterima.

Tabel 2.

Hasil analisis regresi untuk seluruh sektor model 2

\begin{tabular}{|c|c|c|c|c|c|}
\hline \multirow[t]{3}{*}{ Model } & \multicolumn{5}{|c|}{2} \\
\hline & \multicolumn{2}{|c|}{ Unstd. Coef. } & \multirow[t]{2}{*}{$t$} & \multirow[t]{2}{*}{ Sig. } & \multirow{2}{*}{$\begin{array}{c}\text { Pengujian } \\
\text { Hipotesis }\end{array}$} \\
\hline & B & Std. Err. & & & \\
\hline (Const.) & $-5,890$ & 3,318 & $-1,775$ & ,077 & \\
\hline CCC & ,003 & ,005 &,- 048 & ,962 & H6 ditolak \\
\hline GWCTR & 4,593 & ,728 & 6,307 & 000 & H7 diterima \\
\hline CATAR & ,033 & 047 & ,705 & ,481 & H8 ditolak \\
\hline CLTAR & ,233 & 076 & 3,074 & 002 & H9 diterima \\
\hline $\mathrm{CR}$ & ,022 & 010 & 2,323 & ,021 & $\begin{array}{l}\mathrm{H} 10 \\
\text { diterima }\end{array}$ \\
\hline$\alpha$ & $5 \%$ & & & & \\
\hline Adj. $R^{2}$ & 0,162 & & & & \\
\hline F-hit & 16,948 & & & & \\
\hline Sig. F-hit & 0,000 & & & & \\
\hline
\end{tabular}

a. Dependent Variable: ROE

Sumber: Data diolah

Hasil analisis pada Tabel 2. menunjukkan bahwa untuk seluruh sektor, variabel cash conversion cycle dan current assets to total assets ratio tidak berpengaruh terhadap return on equity, yang dibuktikan dengan pengujian $\mathrm{H} 6$ dan $\mathrm{H} 8$ ditolak. Sedangkan variabel gross working capital turnover ratio, current liabilities to total assets ratio dan current ratio berpengaruh positif signifikan terhadap return on equity, yang dibuktikan dengan $\mathrm{H} 7, \mathrm{H} 9$ dan $\mathrm{H} 10$ diterima.

Hasil analisis regresi berganda dan pengujian hipotesis untuk sektor utama disajikan pada Tabel 3 dan Tabel 4 berikut.

Tabel 3.

Hasil analisis regresi untuk sektor utama model 1

\begin{tabular}{|c|c|c|c|c|c|}
\hline \multirow[t]{3}{*}{ Model } & \multicolumn{5}{|c|}{1} \\
\hline & \multicolumn{2}{|c|}{ Unstd. Coef. } & \multirow[t]{2}{*}{$t$} & \multirow[t]{2}{*}{ Sig. } & \multirow[t]{2}{*}{ Ket. } \\
\hline & B & Std. Err. & & & \\
\hline (Const.) & $-6,695$ & 4,560 & $-1,468$ & 149 & \\
\hline CCC &,- 026 & ,012 & $-2,160$ & 036 & H1 diterima \\
\hline GWCTR & 2,785 & ,824 & 3,380 & 002 & H2 diterima \\
\hline CATAR & ,254 & ,083 & 3,067 & ,004 & H3 diterima \\
\hline CLTAR & , 070 & 167 & ,419 & 677 & H4 ditolak \\
\hline$C R$ & 009 & ,015 & 600 &, 552 & H5 ditolak \\
\hline$\alpha$ & \multicolumn{5}{|l|}{$5 \%$} \\
\hline Adj. $R^{2}$ & \multicolumn{5}{|l|}{0,404} \\
\hline F-hit & \multicolumn{5}{|l|}{7,639} \\
\hline Sig. F-hit & \multicolumn{5}{|l|}{0,000} \\
\hline
\end{tabular}

a. Dependent Variable: ROA

Sumber: Data diolah

Hasil analisis pada Tabel 3. menunjukkan bahwa untuk sektor utama, variabel cash conversion cycle, gross working capital turnover ratio dan current assets to total assets ratio berpengaruh terhadap return on assets,yang dibuktikan dengan $\mathrm{H} 1, \mathrm{H} 2$ dan $\mathrm{H} 3$ diterima. Sedangkan variabel current liabilities to total assets ratio dan current ratio tidak berpengaruh terhadap return on assets, yang dibuktikan dengan $\mathrm{H} 4$ dan H5 ditolak.

Tabel 4.

Hasil analisis regresi untuk sektor utama model 2

\begin{tabular}{|c|c|c|c|c|c|}
\hline \multirow[t]{3}{*}{ Model } & \multicolumn{5}{|c|}{2} \\
\hline & \multicolumn{2}{|c|}{ Unstd. Coef. } & \multirow[t]{2}{*}{$\mathbf{t}$} & \multirow[t]{2}{*}{ Sig. } & \multirow{2}{*}{$\begin{array}{l}\text { Pengujian } \\
\text { Hipotesis }\end{array}$} \\
\hline & B & Std. Err. & & & \\
\hline (Const.) & $-6,578$ & 6,276 & $-1,049$ & 300 & \\
\hline $\mathrm{CCC}$ &,- 042 & ,017 & $-2,483$ & ,017 & H6 diterima \\
\hline GWCTR & 2,867 & 1,134 & 2,529 & ,015 & H7 diterima \\
\hline CATAR & ,389 & 114 & 3,422 & ,001 & H8 diterima \\
\hline CLTAR & 236 & 230 & 1,027 & 310 & H9 ditolak \\
\hline CR & ,004 & ,021 & 201 & , 842 & H10 ditolak \\
\hline$\alpha$ & \multicolumn{5}{|l|}{$5 \%$} \\
\hline Adj. $R^{2}$ & \multicolumn{5}{|l|}{0,440} \\
\hline F-hit & \multicolumn{5}{|l|}{8,710} \\
\hline Sig. F-hit & \multicolumn{5}{|l|}{0,000} \\
\hline
\end{tabular}

a. Dependent Variable: ROE

Sumber: Data diolah

Hasil analisis pada Tabel 4. menunjukkan bahwa untuk sektor utama, variabel cash conversion cycle, gross working capital turnover ratio dan current assets to total assets ratio berpengaruh terhadap return on equity, yang dibuktikan dengan $\mathrm{H} 6, \mathrm{H} 7$ dan $\mathrm{H} 8$ diterima. Sedangkan variabel current liabilities to total assets ratio dan current ratio tidak berpengaruh terhadap return on equity, yang dibuktikan dengan H9 dan $\mathrm{H} 10$ ditolak.

Hasil analisis regresi berganda dan pengujian hipotesis untuk sektor kedua disajikan pada Tabel 5 dan Tabel 6 berikut.

Tabel 5.

Hasil analisis regresi untuk sektor kedua model 1

\begin{tabular}{|c|c|c|c|c|c|}
\hline \multirow[t]{3}{*}{ Model } & \multicolumn{5}{|c|}{1} \\
\hline & \multicolumn{2}{|c|}{ Unstd. Coef. } & \multirow[t]{2}{*}{$t$} & \multirow[t]{2}{*}{ Sig. } & \multirow{2}{*}{$\begin{array}{c}\text { Pengujian } \\
\text { Hipotesis }\end{array}$} \\
\hline & B & Std. Err. & & & \\
\hline (Const.) & $\begin{array}{l}-16,498 \\
\end{array}$ & 3,923 & $-4,205$ & , 000 & \\
\hline $\mathrm{CCC}$ & 009 & 010 & ,901 & ,369 & H1 ditolak \\
\hline GWCTR & 6,089 & 832 & 7,321 & , 000 & $\mathrm{H} 2$ diterima \\
\hline CATAR & , 140 & 049 & 2,879 & 005 & H3 diterima \\
\hline CLTAR & 017 & 070 & 237 & ,813 & H4 ditolak \\
\hline$C R$ & , 014 & ,009 & 1,617 & 108 & H5 ditolak \\
\hline$\alpha$ & \multicolumn{5}{|l|}{$5 \%$} \\
\hline Adj. $R^{2}$ & \multicolumn{5}{|l|}{0,298} \\
\hline F-hit & \multicolumn{5}{|l|}{15,189} \\
\hline Sig. F-hit & \multicolumn{5}{|l|}{0,000} \\
\hline
\end{tabular}

a. Dependent Variable: ROA

Sumber: Data diolah

Hasil analisis pada Tabel 5. menunjukkan bahwa untuk sektor kedua, variabel cash conversion cycle, current liabilities to total assets ratio dan current ratio tidak berpengaruh terhadap return on assets, yang dibuktikan dengan $\mathrm{H} 1, \mathrm{H} 4$ dan $\mathrm{H} 5$ ditolak. Sedangkan variabel gross working capital turnover ratio dan current assets to total assets ratio berpengaruh terhadap return on assets, yang dibuktikan dengan $\mathrm{H} 2$ dan $\mathrm{H} 3$ diterima. 
Tabel 6.

Hasil analisis regresi untuk sektor kedua model 2

\begin{tabular}{|c|c|c|c|c|c|}
\hline \multirow[t]{3}{*}{ Model } & \multicolumn{5}{|c|}{2} \\
\hline & \multicolumn{2}{|c|}{ Unstd. Coef. } & \multirow[t]{2}{*}{$t$} & \multirow[t]{2}{*}{ Sig. } & \multirow{2}{*}{$\begin{array}{c}\text { Pengujian } \\
\text { Hipotesis }\end{array}$} \\
\hline & B & Std. Err. & & & \\
\hline (Const.) & $-47,167$ & 8,474 & $-5,566$ & 000 & \\
\hline $\mathrm{CCC}$ & ,036 & 022 & 1,643 & 102 & H6 ditolak \\
\hline GWCTR & 13,528 & 1,797 & 7,526 & 000 & H7 diterima \\
\hline CATAR & 131 & ,105 & 1,243 & ,216 & H8 ditolak \\
\hline CLTAR & ,487 & 153 & 3,180 & 002 & H9 diterima \\
\hline$C R$ & 038 & 019 & 1,995 & ,048 & H10 diterima \\
\hline$\alpha$ & $5 \%$ & & & & \\
\hline Adj. $R^{2}$ & 0,343 & & & & \\
\hline F-hit & 18,315 & & & & \\
\hline Sig. F-hit & 0,000 & & & & \\
\hline
\end{tabular}

a. Dependent Variable: ROE

Sumber: Data diolah

Hasil analisis pada Tabel 6. menunjukkan bahwa untuk sektor kedua, variabel cash conversion cycle dan current assets to total assets ratio tidak berpengaruh terhadap return on equity, yang dibuktikan dengan $\mathrm{H} 6$ dan $\mathrm{H} 8$ ditolak. Sedangkan variabel gross working capital turnover ratio, current liabilities to total assets ratio dan current ratio berpengaruh terhadap return on equity, yang dibuktikan dengan $\mathrm{H} 7, \mathrm{H} 9$ dan $\mathrm{H} 10$ diterima.

Hasil analisis regresi berganda dan pengujian hipotesis untuk sektor ketiga disajikan pada Tabel 7 dan Tabel 8.

Hasil analisis pada Tabel 7. menunjukkan bahwa untuk sektor ketiga, variabel cash conversion cycle, gross working capital turnover ratio, current assets to total assets ratio dan current liabilities to total assets ratio tidak berpengaruh terhadap return on assets, yang dibuktikan dengan $\mathrm{H} 1, \mathrm{H} 2, \mathrm{H} 3$ dan $\mathrm{H} 4$ ditolak. Sedangkan variabel current ratio berpengaruh terhadap return on assets, yang dibuktikan dengan H5 diterima.

Tabel 7.

Hasil analisis regresi untuk sektor ketiga model 1

\begin{tabular}{|c|c|c|c|c|c|}
\hline \multirow[t]{3}{*}{ Model } & \multicolumn{5}{|c|}{1} \\
\hline & \multicolumn{2}{|c|}{ Unstd. Coef. } & \multirow[t]{2}{*}{$t$} & \multirow[t]{2}{*}{ Sig. } & \multirow{2}{*}{$\begin{array}{l}\text { Pengujian } \\
\text { Hipotesis }\end{array}$} \\
\hline & B & Std. Err. & & & \\
\hline (Const.) & 2,527 & 1,947 & 1,298 & 196 & \\
\hline CCC &,- 002 & ,001 & $-1,522$ & , 130 & H1 ditolak \\
\hline GWCTR & 455 & ,426 & 1,068 & ,287 & H2 ditolak \\
\hline CATAR &,- 020 & ,025 &,- 793 & ,429 & H3 ditolak \\
\hline CLTAR & 058 & ,043 & 1,361 & ,175 & H4 ditolak \\
\hline CR &, 023 & ,006 & 3,635 & , 000 & H5 diterima \\
\hline$\alpha$ & \multicolumn{5}{|l|}{$5 \%$} \\
\hline Adj. $R^{2}$ & \multicolumn{5}{|l|}{0,074} \\
\hline F-hit & \multicolumn{5}{|l|}{4,112} \\
\hline Sig. F-hit & \multicolumn{5}{|l|}{0,001} \\
\hline
\end{tabular}

a. Dependent Variable: ROA

Sumber: Data diolah

Hasil analisis pada Tabel 8. menunjukkan bahwa untuk sektor ketiga, variabel cash conversion cycle, gross working capital turnover ratio, current assets to total assets ratio, current liabilities to total assets ratio dan current ratio tidak berpengaruh terhadap return on equity, yang dibuktikan dengan seluruh hipotesis ditolak.
Tabel 8.

Hasil analisis regresi untuk sektor ketiga model 2

\begin{tabular}{|c|c|c|c|c|c|}
\hline \multirow{3}{*}{ Model } & \multicolumn{5}{|c|}{2} \\
\hline & \multicolumn{2}{|c|}{ Unstd. Coef. } & \multirow[t]{2}{*}{$t$} & \multirow[t]{2}{*}{ Sig. } & \multirow{2}{*}{$\begin{array}{l}\text { Pengujian } \\
\text { Hipotesis }\end{array}$} \\
\hline & B & Std. Err. & & & \\
\hline (Const.) & 10,480 & 7,355 & 1,425 & ,156 & \\
\hline CCC &,- 001 & 004 &,- 235 & 814 & H6 ditolak \\
\hline GWCTR & 911 & 1,608 & 567 & ,571 & H7 ditolak \\
\hline CATAR &,- 047 & 095 &,- 500 & 618 & H8 ditolak \\
\hline CLTAR & 193 & ,161 & 1,198 &, 232 & H9 ditolak \\
\hline CR & 010 & 024 &, 442 & 659 & H10 ditolak \\
\hline$\alpha$ & \multicolumn{5}{|l|}{$5 \%$} \\
\hline Adj. $R^{2}$ & \multicolumn{5}{|l|}{0,006} \\
\hline F-hit & \multicolumn{5}{|l|}{0,764} \\
\hline Sig. F-hit & \multicolumn{5}{|c|}{ 0,577 (tidak signifikan) } \\
\hline
\end{tabular}

a. Dependent Variable: ROE

Sumber: Data diolah

Pembahasan

Pengaruh Cash Conversion Cycle terhadap Return on Assets dan Return on Equity

Hasil penelitian pada seluruh sektor, sektor kedua (industri manufaktur), dan sektor ketiga (industri jasa) menunjukkan bahwa cash conversion cycle tidak berpengaruh terhadap return on assets dan return on equity. Berdasarkan pengamatan nilai cash conversion cycle menunjukkan penyebaran yang tidak merata antar perusahaan, ada yang nilai siklus konversi kasnya terlalu cepat dan ada juga yang sangat lama. Nilai siklus konversi kas yang terlalu cepat mengindikasikan bahwa perusahaan membayar utang usaha dalam jangka waktu yang cukup lama sehingga periode penangguhan utang menjadi sangat lama dan nilai siklus konversi kas menjadi sangat singkat bahkan negatif, hal ini tentunya merupakan keputusan keuangan yang tidak baik. Sedangkan nilai siklus konversi kas yang terlalu lama menandakan bahwa piutang dan/atau persediaan yang terlalu banyak dibandingkan dengan penjualan yang dihasilkan sehingga periode konversi persediaan dan periode pengumpulan piutang menjadi terlalu lama. Keduanya mencerminkan pemanfaatan modal kerja untuk meningkatkan penjualan yang tidak efektif. Oleh karena itu, perusahaan harus terus mengontrol pengeluaran kas sampai dengan kas tersebut kembali lagi ke perusahaan dari hasil penjualan. Hasil penelitian ini sejalan dengan temuan beberapa penelitian sebelumnya $[9,10]$.

Hasil penelitian pada sektor utama memperlihatkan bahwa cash conversion cycle memiliki pengaruh negatif signifikan terhadap return on assets dan return on equity. Hasil ini sejalan dengan teori yang dikemukakan oleh Shin dan Soenen bahwa mempersingkat cash conversion cycle akan memberikan laba yang lebih tinggi dan kinerja saham yang lebih baik [14]. Hasil penelitian ini sesuai dengan temuan beberapa penelitian sebelumnya [1,4-8]. 
Pengaruh Gross Working Capital Turnover Ratio terhadap Return on Assets dan Return on Equity

Hasil penelitian pada seluruh sektor, sektor utama, dan sektor kedua menunjukkan bahwa gross working capital turnover ratio berpengaruh positif terhadap return on assets dan return on equity. Hal ini sejalan dengan teori bahwa semakin tinggi rasio perputaran modal kerja maka semakin baik kinerja sebuah perusahaan. Sedangkan pada sektor ketiga (industri jasa), gross working capital turnover ratio tidak berpengaruh terhadap return on assets dan return on equity. $\mathrm{Hal}$ ini dimungkinkan karena nilai rata-rata perputaran modal kerja pada sektor ini rendah yaitu tidak mencapai 2X (2 kali) per tahun, dibandingkan dengan kedua sektor lain. Angka perputaran modal kerja yang ideal adalah 4X (4 kali) per tahun. Perputaran modal kerja yang rendah menunjukkan adanya kelebihan modal kerja yang mungkin disebabkan rendahnya perputaran persediaan, piutang atau adanya saldo kas yang terlalu besar [16].

Hasil penelitian ini sesuai dengan beberapa penelitian sebelumnya yang menemukan pengaruh positif signifikan gross working capital turnover ratio terhadap kinerja perusahaan [11,12]. Namun, hal ini tidak sejalan dengan temuan dari Azam dan Haider yang menemukan pengaruh negatif gross working capital turnover ratio terhadap kinerja perusahaan [1].

\section{Pengaruh Current Assets to Total Assets Ratio terhadap Return on Assets dan Return on Equity}

Hasil penelitian pada sektor utama (industri penghasil bahan baku) dan sektor kedua (industri manufaktur) menunjukkan bahwa current assets to total assets ratio berpengaruh positif terhadap return on assets dan return on equity. Hal ini menunjukkan bahwa nilai aset lancar terhadap total aset yang besar dengan sendirinya meningkatkan profitabilitas perusahaan, karena aset lancar yang terdiri dari kas, persediaan dan piutang dapat dimanfaatkan untuk menciptakan penjualan yang optimal, yang tentunya sejalan dengan teori bahwa semakin besar rasio ini akan semakin baik. Hasil penelitian ini sesuai dengan hasil beberapa penelitian sebelumnya yang menemukan pengaruh positif current assets to total assets ratio terhadap return on assets $[1,5,6,12]$.

Hasil penelitian seluruh sektor dan sektor ketiga (industri jasa) menunjukkan pengaruh negatif tidak signifikan current assets to total assets ratio terhadap return on assets dan return on equity. Hal ini berarti besarnya nilai aset lancar terhadap total aset tidak meningkatkan profitabilitas. Proporsi nilai aset lancar yang dimiliki perusahaan tidak mendukung terciptanya penjualan yang optimal sehingga tidak memberikan keuntungan kepada perusahaan. Hal ini jelas terlihat pada sifat dan karakteristik perusahaan pada sektor ketiga (industri jasa) yang lebih banyak memanfaatkan aset tetapnya dibanding aset lancar. Hasil penelitian ini bertentangan dengan teori yang menyatakan bahwa semakin besar rasio ini akan semakin baik. Temuan ini sesuai dengan hasil penelitian Raheman et al. yang menemukan pengaruh negatif current assets to total assets ratio terhadap kinerja perusahaan [11].

\section{Pengaruh Current Liabilities to Total Assets Ratio terhadap Return on Assets dan Return on Equity}

Hasil penelitian pada seluruh sektor dan sektor kedua (industri manufaktur) menunjukkan bahwa current liabilities to total assets ratio tidak berpengaruh terhadap return on assets, karena nilai utang lancar yang membiayai total aset tidak memengaruhi peningkatan profitabilitas perusahaan. Perusahaan tidak mengandalkan utang lancar dalam menciptakan penjualan. Perusahaan cenderung memanfaatkan ekuitas dalam operasional usahanya untuk menghindari risiko keuangan. Hasil penelitian ini sesuai dengan beberapa penelitian sebelumnya $[1,5,6,11]$.

Hasil penelitian pada seluruh sektor dan sektor kedua (industri manufaktur) menunjukkan bahwa current liabilities to total assets ratio berpengaruh positif signifikan terhadap return on equity. Pengaruh positif menunjukkan bahwa jika nilai utang lancar yang membiayai total aset besar maka pengembalian ekuitas meningkat, dan itu artinya profitabilitas juga meningkat, meskipun perusahaan juga diperhadapkan dengan risiko keuangan yang besar. Current liabilities to total asset ratio (rasio kewajiban lancar terhadap total asset) menekankan pentingnya pendanaan utang bagi perusahaan dengan jalan menunjukkan besarnya aktiva perusahaan yang dibiayai dengan utang jangka pendek. Semakin kecil rasio ini berarti semakin kecil risiko keuangan. Hasil penelitian ini sesuai dengan penelitian Azam dan Haider [1].

Hasil penelitian pada sektor utama (industri penghasil bahan baku) dan sektor ketiga (industri jasa) menunjukkan bahwa current liabilities to total assets ratio berpengaruh positif tidak signifikan terhadap return on assets dan return on equity. Hal ini menunjukkan bahwa meskipun nilai utang lancar yang membiayai total aset besar, profitabilitas perusahaan tidak meningkat. Utang lancar tidak memberikan kontribusi dalam menciptakan penjualan sehingga keuntungan yang diperoleh perusahaan rendah. Perusahaan cenderung memanfaatkan ekuitas dalam 
operasional usahanya untuk menghindari risiko keuangan. Hal ini sesuai dengan salah satu prinsip mendasar dari pendanaan operasional dalam manajemen modal kerja yaitu kemampuan memperoleh laba searah dengan risiko [3]. Hasil penelitian ini sesuai dengan penelitian Vahid et al. [12].

\section{Pengaruh Current Ratio terhadap Return on Assets dan Return on Equity}

Hasil penelitian pada seluruh sektor, sektor kedua (industri manufaktur) dan sektor ketiga (industri jasa) memperlihatkan bahwa current ratio berpengaruh positif terhadap return on assets dan return on equity. Hal ini menunjukkan bahwa nilai rasio lancar yang besar akan meningkatkan profitabilitas perusahaan, karena aset lancar yang mampu menutupi kewajiban lancar yang segera jatuh tempo. Rata-rata nilai current ratio perusahaan yang di teliti mencapai $200 \%$, sehingga bisa dikatakan perusahaan tersebut berada pada kondisi likuid, atau risiko keuangan yang rendah, hal ini sesuai dengan rata-rata return on assets perusahaan yang cukup rendah.

Hasil penelitian ini tidak sejalan dengan teori yang mengatakan kemampuan memperoleh laba berbanding terbalik dengan likuiditas [3]. Semakin tinggi current ratio suatu perusahaan berarti semakin kecil risiko kegagalan perusahaan dalam memenuhi kewajiban jangka pendeknya, yang tentunya akan mengurangi profitabilitas. Hasil penelitian ini sesuai dengan beberapa penelitian sebelumnya [1,2,9-12].

\section{KESIMPULAN DAN SARAN Kesimpulan}

Hasil penelitian pada seluruh sektor menunjukkan bahwa memperpendek cash conversion cycle tidak meningkatkan return on assets maupun return on equity. Kecuali untuk sektor utama menunjukkan bahwa mempersingkat cash conversion cycle akan meningkatkan return on assets maupun return on equity. Hal ini sejalan dengan teori bahwa mempersingkat cash conversion cycle akan memberikan laba yang lebih tinggi atau profitabilitas meningkat.

Gross working capital turnover ratio yang besar akan meningkatkan return on assets dan return on equity pada seluruh sektor, sektor utama (industri penghasil bahan baku), sektor kedua (industri manufaktur) dan sektor ketiga (industri jasa). Hal ini sejalan dengan teori bahwa semakin tinggi rasio perputaran modal kerja maka semakin baik kinerja suatu perusahaan.

Current assets to total assets ratio yang besar akan meningkatkan return on assets dan return on equity pada seluruh sektor, sektor utama (industri penghasil bahan baku), dan sektor kedua (industri manufaktur). Hal ini menunjukkan bahwa aset lancar yang terdiri dari kas, persediaan dan piutang dapat dimanfaatkan untuk menciptakan penjualan yang optimal. Kecuali untuk sektor ketiga (industri jasa) menunjukkan besarnya current assets to total assets ratio tidak meningkatkan return on assets dan return on equity, hal ini berarti besarnya nilai aset lancar terhadap total aset tidak menjamin peningkatan profitabilitas, karena sektor ketiga (industri jasa) lebih banyak memanfaatkan aset tetap dalam operasionalnya dibanding aset lancar.

Current liabilities to total assets ratio yang besar akan menurunkan return on assets pada seluruh sektor. Nilai utang lancar yang besar untuk membiayai total aset akan menyebabkan profitabilitas perusahaan menurun, namun hal ini berarti risiko keuangan yang dihadapi juga kecil, sehingga perusahaan berada pada posisi yang aman. Current liabilities to total assets ratio yang besar akan meningkatkan return on equity pada seluruh sektor dan sektor kedua (industri manufaktur). Hal ini menunjukkan bahwa jika nilai utang lancar yang membiayai total aset besar maka pengembalian ekuitas meningkat, dan itu artinya profitabilitas juga meningkat, meskipun perusahaan juga diperhadapkan dengan risiko keuangan yang besar.

Current ratio yang besar akan meningkatkan return on assets dan return on equity pada seluruh sektor, sektor utama (industri penghasil bahan baku), sektor kedua (industri manufaktur) dan sektor ketiga (industri jasa). Hal ini menunjukkan bahwa nilai rasio lancar yang besar akan meningkatkan profitabilitas perusahaan, karena aset lancar yang mampu menutupi kewajiban lancar yang segera jatuh tempo, sehingga bisa dikatakan perusahaan tersebut berada pada kondisi likuid, atau risiko keuangan yang rendah, hal ini sesuai dengan rata-rata return on assets perusahaan yang cukup rendah.

\section{Keterbatasan dan Saran Kepada Peneliti Selanjutnya}

Pada pengukuran komponen modal kerja, dimana tidak dilakukan analisis secara spesifik komponen kas seperti halnya piutang usaha dan persediaan. Analisis hanya dilakukan terhadap keseluruhan modal kerja yang didalamnya termasuk komponen kas, sehingga hasil penelitianpun tidak menggambarkan secara detail pengaruh kas terhadap profitabilitas.

Hasil penelitian pada sektor jasa menunjukkan bahwa sektor ini memiliki sifat dan karakteristik dari perusahaannya yang lebih cenderung memanfaatkan aktiva tetap daripada 
aktiva lancar, sehingga perlu dipertimbangkan apabila ingin diteliti manajemen modal kerjanya.

\section{UCAPAN TERIMA KASIH}

Terima kasih yang tak terhingga kami sampaikan kepada:

1. Rektor Universitas Pattimura

2. Rektor Universitas Brawijaya

3. Dekan FKIP Universitas Pattimura

4. Dekan FEB Universitas Brawijaya

5. Bapak. I. Rolobessy, SE., MM. (Dirut. Bank Maluku)

\section{DAFTAR PUSTAKA}

[1] Azam, M, dan S.I. Haider. 2011. Impact Of Working Capital Management On Firms' Performance: Evidence From Non-Financial Institutions Of KSE-30 Index, Interdisciplinary Journal of Contemporary Research In Business. Vol 3. No 5

[2] Raheman, A., and M. Nasr. 2007. Working Capital Management And Profitability - Case Of Pakistani Firms, International Review of Business Research Papers. Vol.3. No.1. March. Pp.279- 300

[3] Van Horne, J.C., dan J.M. Wachowicz. 2012. Fundamental of Financial Management. 13th ed. Dewi Fitriasari, S.S., Msi., Ak. dan Deny Arnos Kwary, Mhum (penerjemah). Prinsipprinsip Manajemen Keuangan, Edisi 13. Jilid I. Jakarta: Penerbit Salemba Empat

[4] Teruel, P.J.G., dan P.M. Solano. 2007. Effects of working capital management on SME profitability, International Journal of Managerial Finance. Vol. 3. No. 2. pp. 164177

[5] Nor Edi Azhar dan Noriza. 2010. Working capital management: The effect of market valuation and profitability in Malaysia, International Journal of Business and Management. Vol. 5. No. II. November

[6] Pouraghajan, A., dan M. Emamgholipourarchi. 2012. Impact of Working Capital Management on Profitability and Market Evaluation: Evidence from Tehran Stock Exchange, International Journal of Business and Social Science. Vol. 3. No. 10

[7] Mansoori, E., dan Datin Dr. Joriah Muhammad. 2012. The Effect of Working Capital Management on Firm's Profitability: Evidence from Singapore, Interdisciplinary Journal of Contemporary Research In Business. Vol 4. No 5

[8] Tauringana, V., dan G.A. Afrifa. 2013. The Relative importance of working capital management and its components to SME's profitability, Journal of Small Business and
Enterprise Development. Vol. 20. No. 3. 2013. pp. 453-469

[9] Afeef, M. 2011. Analyzing the Impact of Working Capital Management on the Profitability of SME's in Pakistan, International Journal of Business and Social Science. Vol. 2. No. 22

[10] Uchenna, A.W., I.M. Okwo, dan D.O. Ugwunta. 2012. Effects of working capital management on profitability: Evidence from the topfive beer brewery firms in the world, Asian Economic and Financial Review. 2(8):966-982

[11] Raheman, A., T. Afza, A. Qayyum, dan M.A. Bodla. 2010. Working Capital Management and Corporate Performance of Manufacturing Sector in Pakistan, International Research Journal of Finance and Economics. ISSN 14502887 Issue 47

[12] Vahid, T.K., G. Elham, A.K. Mohsen, dan E. Mohammadreza. 2012. Working capital management and corporate performance: evidence from Iranian companies, Procedia Social and Behavioral Sciences. 62 (2012) $1313-1318$

[13] Sugiyono. 2013. Metode Penelitian Bisnis. Bandung: Penerbit Alfabeta

[14] Brigham E.F., dan Houston J.F. 2013. Essentials of Financial Management. 11th ed. A.A. Yulianto (penerjemah). Dasar-Dasar Manajemen Keuangan, Edisi 11. Jilid 2. Jakarta: Penerbit Salemba Empat

[15] Munawir, S. 2014. Analisis laporan keuangan. Yogyakarta: Liberty

[16] Moeljadi. 2006. Manajemen keuangan, Pendekatan kuantitatif dan kualitatif. Jilid 1. Malang: Bayumedia Publishing

http://www.idx.co.id 
Lampiran

Tabel

Deskripsi Variabel Penelitian

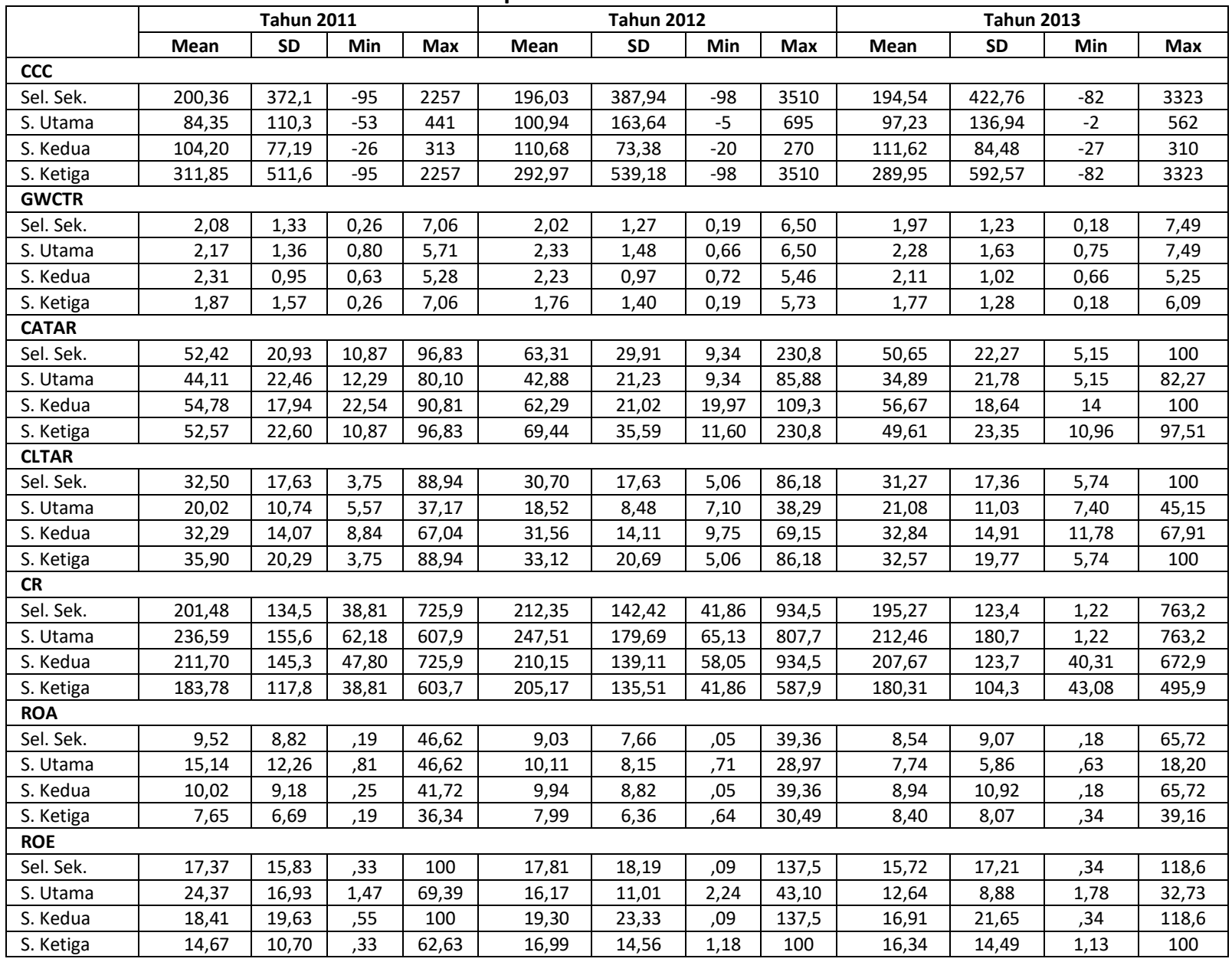

Sumber: output SPSS (lap. keu. data diolah) 